1 Chelsea and Westminster Hospital, London, UK

2 Frimley Park Hospital, Surrey, UK

helen.grote@nhs.net Follow Helen Grote on Twitter @helengrote Follow Fizz Izagaren on Twitter @DocFizzabella Cite this as: BMJ 2020;369:m2372 http://dx.doi.org/10.1136/bmj.m2372 Published: 15 June 2020

\title{
Covid-19: The communication needs of $D /$ deaf healthcare workers and patients are being forgotten
}

\section{We need to ensure that in our response to covid-19, the rights of those with hearing loss are not forgotten, say Helen Grote and Fizz Izagaren}

\section{Helen Grote, ${ }^{1}$ Fizz Izagaren ${ }^{2}$}

We are two deaf doctors who rely on lipreading in our daily work. The debates about personal protective equipment (PPE) during this coronavirus outbreak have revolved around adequate supplies ${ }^{1}$ and whether the fit testing and face masks supplied by hospital trusts give enough protection. ${ }^{2}$ The communication needs of those who rely on lipreading have been completely overlooked.

At present, we have found only one company in the world that produces transparent face masks approved for use in healthcare settings (https://safenclear.com). These are currently unavailable, and, despite involving our respective hospital trusts, the BMA, and NHS England, there are no transparent masks available for use in healthcare settings in the UK.

On a practical level, this means participating in discussions on ward rounds is all but impossible-aside from reading entries in patient notes and the pre- and post-round discussions in non-clinical settings where masks can be removed. In a medical emergency that requires PPE to be worn, and where safe and effective communication is essential, this difficulty is a concern.

Similarly, the effect on patients has been overlooked. Around one in six people in the UK live with hearing loss-and in people over the age of 70 an estimated $70 \%$ have hearing loss. ${ }^{3}$ The use of masks has made communication with healthcare professionals harder for many of these patients, and yet the General Medical Council states communication "in a way patients can understand" is vital for informed consent, patient care, and safety. ${ }^{4}$ Face coverings don't just affect those who lipread; studies have shown that $60-70 \%$ of communication is based on non-verbal cues from lip patterns and facial expressions, ${ }^{5}$ which are essential for anyone with communication difficulties.

While we recognise that masks and non-medical face coverings do reduce viral transmission from coughs and sneezes, the attitude of policy makers and the public towards the $\mathrm{D} /$ deaf community has been disappointing.

Politicians including Sadiq Khan ${ }^{6}$ and high profile doctors such as Twitter's Dr Ellie and Trisha Greenhalgh have supported campaigns such as \#MasksforAll. In an analysis in The BMJ Greenhalgh and colleagues concluded that, despite limited evidence, masks "could have a substantial impact on transmission with a relatively small impact on social and economic life." 7
The negative impact of \#MasksforAll on the social and communication needs of the $\mathrm{D} /$ deaf community is, however, substantial. It risks those with hearing loss becoming increasingly isolated, with all the detrimental mental health consequences that can ensue.

Those advocating the mass wearing of masks have overlooked its impact on the D/deaf community. In the rare instances that the matter has been tackled, it is dismissed as a short term concession that the community could make for the greater good of society. Yet the time needed to produce a safe, effective vaccine against covid-19, together with the acknowledgment of England's chief medical officer that social distancing measures will need to be in place for "really quite a long period of time," ${ }^{8}$ makes it likely that the wearing of masks will become normalised in the longer term.

In a society where manufacturers rushed to produce ventilators and generous communities produced scrubs and homemade visors, no one, despite our calls for help, has been able to produce a suitable transparent mask in this time. Although one thoughtful US healthcare student has produced a pattern for a homemade transparent mask, ${ }^{9}$ these are not classified as suitable for use in a healthcare setting, where type IIR or $\mathrm{FFP}_{3}$ masks are required.

We, as a society and as a body of healthcare professionals, need to ensure that in our response to covid-19, the rights of those with hearing loss are not forgotten.

We would encourage all healthcare professionals to consider the communication needs of their $\mathrm{D} /$ deaf patients. Apps, such as Google's Live Transcribe, may help to decipher speech from behind a mask in quiet settings. Clear signs and pictures can also assist with communication; resources such as Cardmedic, a digital package of communication flashcards, can be helpful in some instances. Written notes, however, are not always an effective means of communication for those whose first language is British Sign Language, as the grammatical structure is entirely different.

The lack of support has been one of the hardest challenges we have faced at work during the pandemic. It leaves us and our D/deaf patients feeling isolated and ignored. Reading articles and tweets about the importance of masks, with no consideration of the impact on the $\mathrm{D} /$ deaf, leads us to conclude that policy makers and academics have forgotten about 
the importance of equality impact assessments in this area.

We want-and need-access to suitable transparent masks in healthcare settings and are keen to work in collaboration with manufacturers to enable this to happen. Most of all, please advocate on our behalf. As we have heard often, tackling this current pandemic together "is a marathon, not a sprint." A focus on ensuring access to transparent masks, and enabling safe, effective communication for healthcare workers and patients with hearing loss will be a legacy for years to come.

Competing interests: We have read and understood BMJ policy on declaration of interests and declare the following interests: none.

1 BMA. Doctors still without adequate supplies of PPE, major BMA survey finds. 18 April 2020 www.bma.org.uk/news-and-opinion/doctors-still-without-adequate-supplies-of-ppe-major-bmasurvey-finds.

2 Junior doctors at London hospital hit out at "inadequate" masks and PPE amid coronavirus pandemic. ITV News. 11 April 2020. www.itv.com/news/2020-04-11/coronavirus-patients-arebeing-treated-by-junior-doctors-with-inadequate-protective-masks-and-ppe.

3 Action on Hearing Loss. Facts and figures. https://actiononhearingloss.org.uk/about-us/researchand-policy/facts-and-figures.

4 General Medical Council. Good Medical Practice. 25 April 2013. www.gmc-uk.org/static/documents/content/Good_medical_practice_-_English_1215.pdf.

5 The Definitive Book of Body Language." New York Times. 24 September. www.nytimes.com/2006/09/24/books/chapters/0924-1st-peas.html.

6 Coronavirus: London mayor Sadiq Khan calls for “compulsory” face masks. BBC News. 16 April 2020. www.bbc.co.uk/news/uk-england-london-52312906.

7 Greenhalgh T, Schmid MB, Czypionka T, Bassler D, Gruer L. Face masks for the public during the covid-19 crisis. BMJ2020;369:m1435. doi: 10.1136/bmj.m1435 pmid: 32273267

8 UK will need social distancing until at least end of year, says Whitty. Guardian. 22 April 2020 www.theguardian.com/world/2020/apr/22/uk-will-need-social-distancing-until-at-least-end-ofyear-says-whitty.

9 This see-through mask lets the deaf communicate while staying safe. Forbes 2020. www.forbes.com/sites/marleycoyne/2020/04/04/this-see-through-mask-lets-the-deaf-communicate-while-staying-safe/\#714b0efa5257.

This article is made freely available for use in accordance with BMJ's website terms and conditions for the duration of the covid-19 pandemic or until otherwise determined by BMJ. You may use, download and print the article for any lawful, non-commercial purpose (including text and data mining) provided that all copyright notices and trade marks are retained. 